\title{
CYPRINGLEA (CYPERACEAE) REVISITED, A NEW COMBINATION AND STATUS
}

\author{
Anton A. RezniceK ${ }^{1}$ And M. Socorro GonZÁlez Elizondo²
}

${ }^{1}$ University of Michigan Herbarium, 3600 Varsity Drive, Ann Arbor, MI, 48108-2287 U.S.A.reznicek@umich.edu

${ }^{2}$ Instituto Politécnico Nacional, Centro Interdisciplinario de Investigación para el Desarrollo Integral Regional, Unidad Durango. Sigma s.n. Fraccionamiento 20 de Noviembre II, 34220 Durango, Durango, México. herbario_ciidir@yahoo.com.mx

\begin{abstract}
Cypringlea (Cyperaceae), a Mexican endemic genus segregated from Scirpus, includes three species. Cypringlea evadens, previously treated as a variety or under synonymy of C. analecta, is raised here to the specific level. It differs in the degree of inflorescence compounding, proportion of spikes that are peduncled, total number of spikes, as well as leaf width and the proportionate length of inflorescence bracts. A key to distinguish the species, as well as descriptions and data on distribution and habitat are given. Cypringlea analecta is newly recorded for Nuevo León, Tamaulipas and Querétaro, C. coahuilensis, previously known only from the type collection in Coahuila, is recorded also from Nuevo León, and C. evadens is newly recorded for Guerrero and Oaxaca.
\end{abstract}

Key words: Cyperaceae, Cypringlea, endemism, Mexico, Scirpus.

\section{RESUMEN}

Cypringlea (Cyperaceae) es un género segregado de Scirpus, endémico de México, con tres especies. Cypringlea evadens, previamente considerada como variedad de $C$. analecta o bajo sinonimia de ésta, se reconoce aquí a nivel específico, difiriendo en el grado de división de la inflorescencia, proporción de espigas pedunculadas, número total de espigas, anchura de la hoja y longitud proporcional de las brácteas de la inflorescencia. Se presenta una clave para distinguir las especies, así como descripciones y datos sobre su distribución y hábitat. Cypringlea analecta se cita por primera vez para Nuevo León, Tamaulipas y Querétaro; C. coahuilensis, conocida previamente sólo de la localidad tipo en Coahuila, se da a conocer para Nuevo León; y C. evadens se registra por primera vez para Guerrero y Oaxaca.

Palabras clave: Cyperaceae, Cypringlea, endemismo, México, Scirpus. 
Cypringlea M. T. Strong (Cyperaceae), a Mexican endemic genus previously considered as a part of Scirpus, was segregated as a genus (Strong, 2003) because of differences in habitat, leaf blade development and morphology, inflorescence morphology, the possession of rudimentary perianth bristles, and morphology of the embryo. It differs from most Mexican Scirpeae in having well developed leaves and foliaceous involucral bracts, characters shared with Bolboschoenus and Scirpus sensu stricto. Cypringlea is distinguished from them because the perianth bristles are shorter than the achene, smooth or with antrorse to divergent, blunt, inconspicuous protuberances (vs. shorter to much longer than achene, smooth or with retrorse, acute teeth), embryo of the Carex-type (vs. of the Schoenoplectustype and Fimbristylis-type, respectively), and in being terrestrial plants (vs. aquatic, subaquatic or of very humid places). Additionally, Cypringlea differs from Scirpus sensu stricto in having spikelets with (0-)1-4 empty basal scales (vs. basal scales with flower). From Bolboschoenus it differs in the absence of corms at the base (vs. corms present), presence of a ligule (vs. ligule absent), spikelets much narrower (1-3.5 mm vs. $5-10 \mathrm{~mm}$ ), floral scales glabrous, obtuse, acute, or acuminate, emucronate or with a short mucro (vs. puberulent, notched and awned), and shorter achenes (0.7$2.2 \mathrm{~mm}$ vs. 2.3-4 mm). These genera are members of the tribe Scirpeae Kunth ex Dumortier (Strong, 2003), one of the less cohesive groups among sedges (Bruhl, 1995). Following Goetghebeur's (1998) classification, they belong to the subfamily Cyperoideae Süssenguth.

When Strong (2003) published the genus Cypringlea, he did not recognize the entity that had been described from Chiapas as Scirpus analecti var. evadens, noting that "The specimen Purpus 2889 (GH, US), from Puebla, is intermediate between the fascicled spikelets of the type material and that of $S$. var. evadens in having both solitary and fascicled spikelets at ray tips." The Chiapas collection was considered to represent a disjunct population. Strong's observations about the spikelets are correct. However, examination of a number of additional collections has shown that there are nevertheless two entities involved in Strong's C. analecta: the typical entity, and another element, more southern, including the type of Scirpus analecta var. evadens. The differences, however, are not simply peduncled versus sessile spikes. The diagnostic features involve the degree of inflorescence compounding, especially as represented by the distalmost inflorescence branches, and also the proportion of spikes that are peduncled as well as the total number of spikes. In addition the two entities differ in leaf width and the proportionate length of inflorescence bracts.

In collections from northeastern Mexico, from Nuevo León and Tamaulipas to Hidalgo, the distalmost inflorescence branches are terminated by fascicles of 2-7 sessile or nearly sessile (peduncles not more than $5 \mathrm{~mm}$ long) spikelets; long-pe- 
duncled spikelets, if any, are only at proximal inflorescence nodes. Inflorescences have 25 -ca. 200 spikelets with only $0-15 \%$ peduncled. The inflorescences also have longer bracts, with the longest (lowest) involucral bract being 1.5-2.6 times as long as the inflorescence (Fig. 1). This northern plant is generally more robust and wider leaved, with the widest leaves on the plant 5.5-7.4 mm wide.

Collections from southern Mexico, from SW Puebla, Oaxaca, Guerrero, and Chiapas, have the distalmost inflorescence branches terminated by fascicles of 2-4 spikelets, with the lower spikelets of many or most fascicles pedunculate; the longer peduncles 5-24 mm long. Also, the inflorescences have 6-60 spikelets with $20-80 \%$ of the spikelets peduncled. The inflorescence bracts are typically more or less equal to the inflorescence, the longest ranging from 0.7-1.5 times as long as the inflorescence (Fig. 2). The more southern entity is also more delicate and lax, and has the widest leaves only 2.8-5(5.8) mm wide. The two groups are compared in Fig. 3, using inflorescence bract proportions and widest leaf width. The differences between both taxa are enough to raise the southern entity to the specific rank, retaining the epithet evadens as its name.

Cypringlea M. T. Strong, Novon 13: 123. 2003. Scirpus sect. Oxycaryum (Nees) Beetle (p.p.); Scirpus sect. Androcoma (Nees) Benth. \& Hook. (p.p.), N. Amer. Flora 18: 481.1947.

Key to species:

1. Leaves filiform, $0.3-0.8 \mathrm{~mm}$ wide; culms obtusely trigonous to compressedtrigonous; 0-1 sterile scales at the base of the spikelet (excluding the prophyll); anthers 1.7-2.8 mm long; achene 1.1-1.5 mm wide C. coahuilensis

1. Leaves $2-7.4 \mathrm{~mm}$ wide; culms triquetrous; $2-4$ sterile scales at the base of the spikelet (excluding the prophyll); anthers 0.6-1.8 mm long; achene (0.7-)0.8-

$1.1 \mathrm{~mm}$ wide

2. Ultimate (distalmost) inflorescence branches terminated by fascicles of 2-7 \pm sessile spikelets, peduncles, if any, $<5 \mathrm{~mm}$ long (long-pedunculate spikelets may occur at more proximal inflorescence nodes); longest inflorescence bract 1.5-2.6 times as long as the inflorescence; spikelets $25-200,0-15 \%$ peduncled; widest leaves 5.5-7.4 mm wide C. analecta

2. Ultimate (distalmost) inflorescence branches terminated by fascicles of 2-4 spikelets, with the lowest spikelets of many or most fascicles individually pedunculate, with longer peduncles 5-24 mm long, longest inflorescence bract 0.7-1.5 times as long as the inflorescence; spikelets $6-60,20-80 \%$ peduncled; widest leaves $2.8-5(-5.8) \mathrm{mm}$ wide C. evadens 


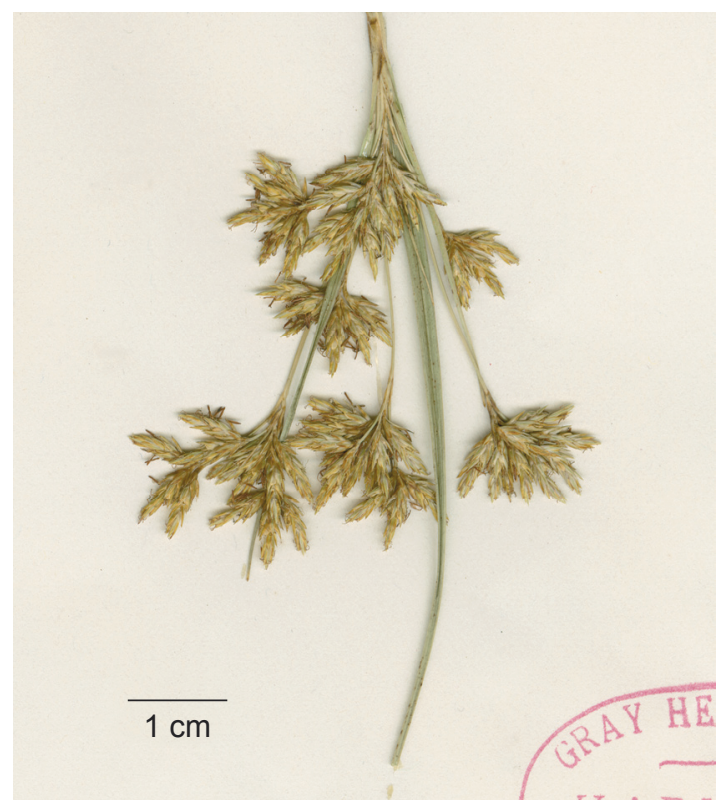

Fig. 1. Inflorescence of Cypringlea analecta (Beetle) M. T. Strong [Purpus 5454 (GH, isotype)].

Cypringlea analecta (Beetle) M. T. Strong, Novon 13: 125. 2003. Scirpus analecta Beetle, Brittonia 5: 148. 1944 (as Scirpus analecti). Type: Mexico. San Luis Potosí, Minas de San Rafael, May 1911, C. A. Purpus 5454 (holotype, NY; isotypes, F, GH, MO, UC (has date of July 1911 according to Strong, 2003), US).

Plants in small clumps with usually solitary culms; culms $40-85 \mathrm{~cm}$ tall, 1.5 $2.5 \mathrm{~mm}$ wide, erect to spreading, triquetrous, coarsely ribbed, the angles antrorsely scabrous distally, smooth proximally. Leaves 6-14, essentially basal; sheaths 3-13 $\mathrm{cm}$ long, whitish to stramineous, strongly ribbed, old sheath bases brownish, becoming slightly fibrous, the inner band whitish-hyaline to brown, membranous, finely veined, the apex concave; ligule rounded, 1-4(-9) $\mathrm{mm}$ long, the free portion brownish, 0.2-0.3 $\mathrm{mm}$ wide; blades linear, $10-80 \mathrm{~cm}$ long, 3.5-7.4 $\mathrm{mm}$ wide, the widest ca. 5.5-7.4 mm, more or less flat to somewhat V-folded, margins and keel of midvein antrorsely scabrous, especially distally, the apex becoming triquetrous. Inflorescence terminal, umbellate, 5-19 $\mathrm{cm}$ long, 3-7 $\mathrm{cm}$ wide, with 6-10 primary involucral bracts, the lowermost 1-2 leaf-like and exceeding the inflorescence, the uppermost setaceous, lowest involucral bract 10-30 cm long, 1.5-2.6 times as long 


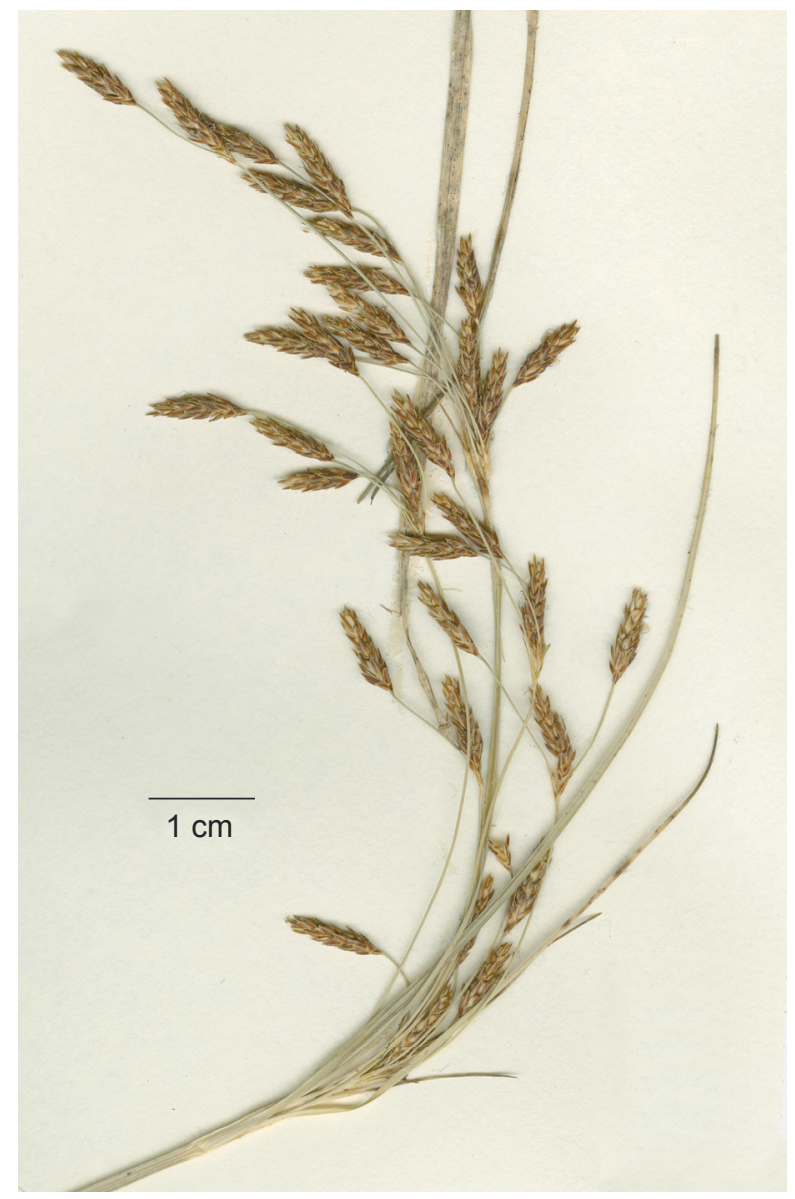

Fig. 2. Inflorescence of Cypringlea evadens (C. D. Adams) Reznicek \& S. González [Breedlove $11204(\mathrm{MICH})]$.

as the inflorescence; primary rays 5-15 ascending to curving with age, at least the thinnest more or less flexuous, flattened or compressed-trigonous, antrorsely scabrous on margins distally, smooth proximally, the longest $5-11 \mathrm{~cm}$, second, third, and occasionally fourth order branching present, with the spikelets ultimately sessile or rarely short-peduncled $(<5 \mathrm{~mm})$ in fascicles of 2-7 or rarely solitary at tips of primary or second order branches. Spikelets 25-200 per inflorescence, not more than $15 \%$ peduncled, linear-ellipsoid, 4-9.5 $\mathrm{mm}$ long, 1.7-2.7 $\mathrm{mm}$ wide, cuneate at base, acute at apex; scales somewhat spreading, loosely spirally arranged, with 24 sterile scales at the base of the spikelet (excluding the prophyll) and 8-25 fertile 


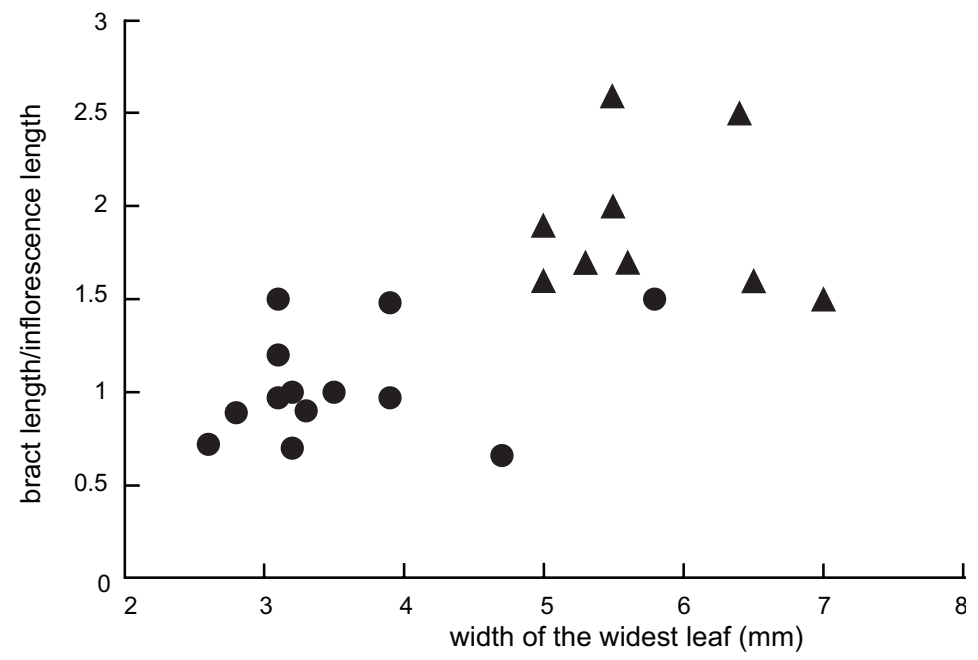

Fig. 3. Scatter diagram comparing Cypringlea analecta and C. evadens on the basis of the bract length/inflorescence length ratio and width of the widest leaf. Cypringlea evadens, spikelets often with peduncles $>5 \mathrm{~mm}$ long; $\Delta$ Cypringlea analecta, spikelets all essentially sessile.

scales; fertile scales 1.7-2.7 $\mathrm{mm}$ long, 0.9-1.3 mm wide, ovate to ovate elliptic, obtuse to rounded, yellowish to pale brown with a green to brown, 3-nerved mid-zone and hyaline margins, partially enveloping the achene. Achene 1.3-1.6 mm long, 0.9-1.1 $\mathrm{mm}$ wide, dark brown, obovate to elliptic-obovate, flattened-trigonous to more or less plano-convex or even slightly concavo-convex, rounded to more or less cuneate to a sessile base, rounded to the apex, with an indistinct collar and sometimes a very short apiculus, finely papillose; style branches reddish, feathery with elongate papillae. Anthers 1.1-1.8 mm long, apiculate.

Known from Nuevo León, Tamaulipas, San Luis Potosí, Querétaro, and Hidalgo. A reference from Michoacán (Espejo and López-Ferrari, 1997) has not been confirmed. From the western slopes of the Sierra Madre Oriental, scarce to locally abundant in rocky sites, often on karstic limestone substrate on slopes and ravines. Usually in humid areas with temperate pine-oak forest. Alt. 1485-2250 m. Common name: zacate.

Specimens mapped (Fig. 4): Hidalgo, Jacala, Jul 1936, E. Lyonnet 1318 (US); Nuevo León, Mpio. Galeana, La Poza to Río de San José, gypsum hillside, 1450 m, 31 May 1992, Hinton et al. 22037 (IEB, MICH); ibid., 1465 m, 18 Sep 1993, Hinton et al. 23337 (IEB); ibid., 24 March 1992, Hinton et al. 21875 (IEB); Galeana-Rayo- 


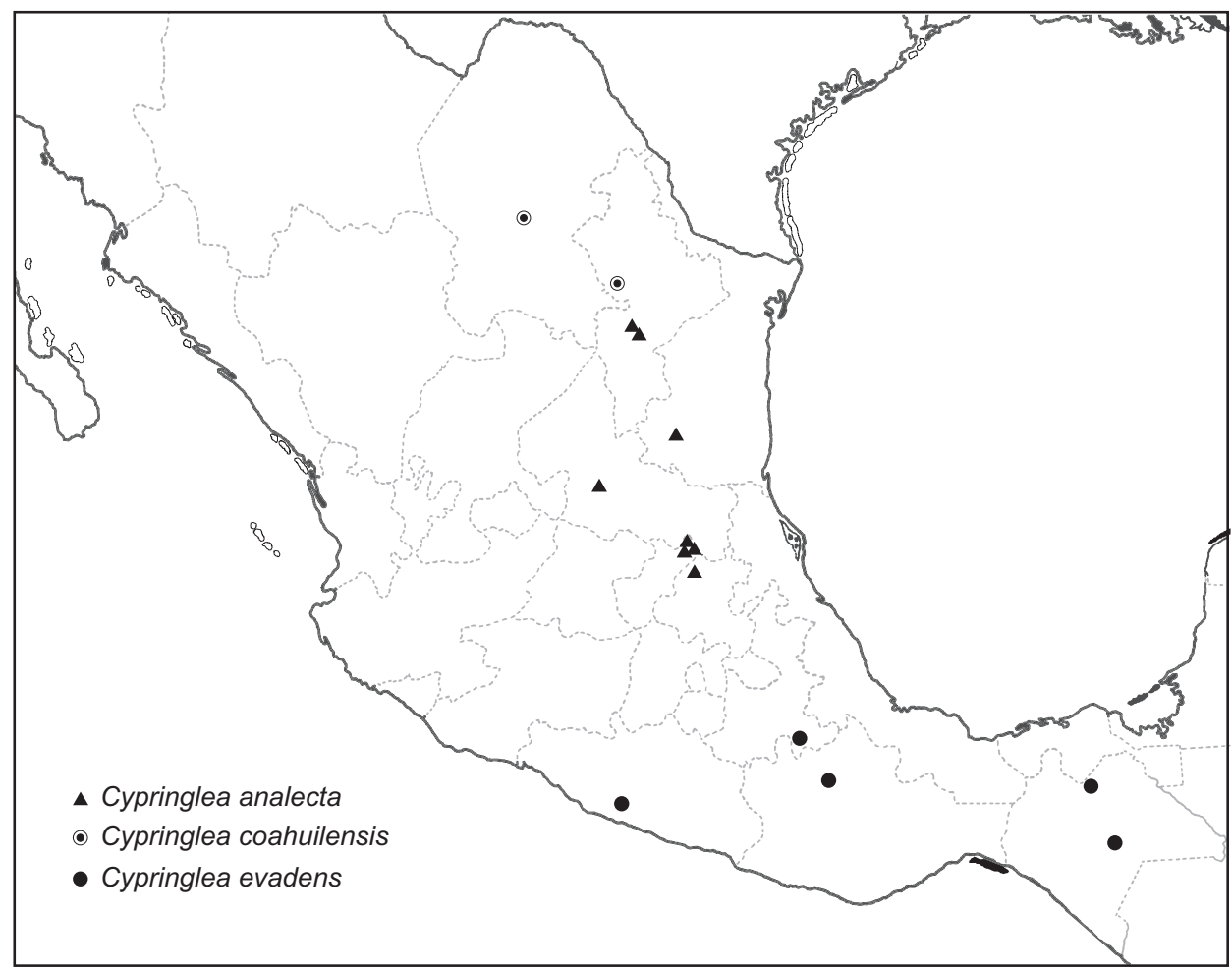

Fig. 4. Distribution of Cypringlea analecta, C. coahuilensis and C. evadens.

nes, bushy hillside, 1485 m, Hinton et al. 24238 (ANSM, CIIDIR, IEB); QuERÉTARO, Mpio. Jalpan, 5-6 km al noroeste de San Juan de los Durán, El Arroyo, 1500-1600 m, 21 Aug 1991, B. Servín 1270 (CIIDIR, IEB, MICH); Mpio. Jalpan, El Ojo de Agua, San Juan de los Durán, 2127'41" N 99¹0'42" W, 1300 m, cañada húmeda con elementos del bosque mesófilo de montaña entre el bosque de Pinus greggii, 24 Oct 2003, S. Zamudio y L. Hernández 12567 (IEB); Mpio. Jalpan, 1.5 km al SE de Valle Verde por el camino a La Cercada, 2130' N 989'25" W, bosque mesófilo de montaña, sobre ladera de rocas calizas, $1400 \mathrm{~m}, 24 \mathrm{Sep}$ 2002, S. Zamudio y V. Steinmann 12108 (IEB); Mpio. Landa de Matamoros, 10 km al NW de El Madroño, sobre el camino a Tres Lagunas, J. Rzedowski 44095 (IEB); Mpio. Landa de Matamoros, $10 \mathrm{~km}$ al NW de El Madroño, sobre el camino a Tres Lagunas, J. Rzedowski 44100 (CIIDIR, IEB); Mpio. Landa de Matamoros, El Llano Chiquito, $21^{\circ} 23.009^{\prime \prime} \mathrm{N}$ 999.7' W, 1900 m, S. Zamudio y E. Carranza 11163 (CIIDIR, IEB, MICH); Mpio. 
Landa de Matamoros, Llano Chiquito valley, along trail to Llano del Conejo, below El Puerto del Conejo, 21 ${ }^{\circ} 24^{\prime}$ N, 997' W, 2250 m, 14 Jun 2000, A. A. Reznicek 11094 with S. Zamudio \& G. Ocampo (CIIDIR, IEB, MICH); San Luis Potosí, San Jose Pass, 15 Aug 1890, C. G. Pringle 3175 (F, GH, ISC, K, MICH, MO, MU, NY, US, VT) (the nomen nudum Scirpus potosinus was based on this number); TAMAULIPAS, 16 km sur de Palmillas, 1600 m, en arroyo seco, chaparral, dominantes Pinus, Quercus, Rhus, Juniperus, Croton, arbustos de leguminosas y compuestas, 15 Oct 1984, A. McDonald 1089 (IEB).

Cypringlea coahuilensis (Svenson) M. T. Strong, Novon 13: 129. 2003. Scirpus coahuilensis Svenson, J. Arnold Arbor. 25(1): 46. 1944. Type: Mexico. Coahuila, western Coahuila, high limestone ridge with forest of Pinus pinceana, SW end of the Sierra de la Fragua, 1-2 km N of Puerto Colorado; abundant, coarse tufts 1-3 ft tall, on rocky slopes with scrub oaks and Pinus pinceana, 2 Sep 1941, I. M. Johnston 8763 (holotype: GH; isotypes: LL, TEX).

Plants in dense clumps with many culms; culms $24-50 \mathrm{~cm}$ tall, $0.3-1 \mathrm{~mm}$ wide, erect, obtusely trigonous to compressed-trigonous (about $0.2 \mathrm{~mm}$ thick), coarsely ribbed, smooth or almost so. Leaves 3-8, essentially basal; sheaths $2.2-4 \mathrm{~cm}$ long, greenish-white to ochraceous, strongly ribbed, old sheath bases ochraceous to brown, sometimes becoming fibrous, the ventral side and margins scarious, hyaline, colorless or yellowish, easily torn, finely veined, the apex shallowly concave; ligule irregularly truncate to rounded, up to $1.6 \mathrm{~mm}$ long, the free portion stramineous, $0.2 \mathrm{~mm}$ wide; blades filiform, $6-42 \mathrm{~cm}$ long, 0.3-0.8 mm wide, curling, U-folded to V-folded, margins strongly antrorsely scabrous, especially proximally, the apex becoming triquetrous. Inflorescence terminal, reduced, the spikelets nearly sessile in a single fascicle (ultimately solitary but the peduncles very reduced, mostly $0.3-1$ $\mathrm{mm}$ long), often other spikelets peduncled, forming 2-3 subcontiguous fascicles, the peduncle ascending, compressed-trigonous to more or less terete, smooth or slightly antrorsely scabrous distally; the complete inflorescence $0.8-3 \mathrm{~cm}$ long, $1-2 \mathrm{~cm}$ wide, with 1-3 involucral bracts, the primary exceeding the inflorescence, setaceous, 2.7$16 \mathrm{~cm}$ long. Spikelets 3-9 per inflorescence, ovate-ellipsoid, 6-10.5 mm long, 2-3 mm wide, acute to acuminate at base and apex; scales somewhat spreading, loosely spirally arranged, with $0-1$ sterile scales at the base of the spikelet (excluding the prophyll) and 14-25 fertile scales; fertile scales 2.8-5 mm long, 1.2-2.6 mm wide, ovate to oblong, acute to acuminate, often with the midvein prolonged as a short mucro, withish to stramineous translucent with a pale green to stramineous 3-nerved 
mid-zone, the margins scarious, hyaline. Achene 1.6-2.1 $\mathrm{mm}$ long, 1.1-1.5 mm wide, dark brown, ellipsoid to broadly obovoid, flattened-trigonous to more or less planoconvex, the adaxial face slightly concave, more or less cuneate to a sessile base, rounded to the short apiculate apex (the style base persistent as an apiculus 0.1-0.2 $\mathrm{mm}$ long, or up to $0.4 \mathrm{~mm}$ long but easily broken), finely papillose; style branches stramineous to pale reddish, feathery with elongate papillae. Anthers 1.7-2.8 mm long, apiculate.

Endemic to northeastern Mexico, it is known only from the southern part of the Sierra de La Fragua, in Coahuila, and from central-east Nuevo León. It is one of the few sedges adapted to desert habitats in Mexico (Reznicek, 2005).

The plant from Nuevo León differs from the description of the type of $C$. coahuilensis as follows: slender culms, 0.3-0.4 mm wide (vs. 0.6-1 mm wide); basal sheats lighter colored, old sheath bases greenish white to ochraceous, not persistent (vs. dark brown, persistent); 3-4 spikelets (a fascicle of 2-3 nearly sessile spikelets and a solitary spikelet on a peduncle 8-15 mm long) (vs. spikelets 3-9 per inflorescence); longer fertile scales: $3.6-5 \mathrm{~mm}$ long, 1.2-1.8 mm wide (vs. 2.8-4 mm long, 1.6-2.6 mm wide); longer achenes: 2-2.1 mm long, 1.1-1.2 mm wide (vs. 1.6-2 mm long, 1.1.-1.5 mm wide) which are narrowly ellipsoid to narrowly obovoid (vs. obovoid to widely obovoid); apiculate achenes, the beak up to $0.4 \mathrm{~mm}$ long, or broken but still evident (vs. unbeaked achenes); and longer anthers: 2-2.8 mm long (vs. 1.7$2.2 \mathrm{~mm}$ long). The slender culms and leaves and the reduced inflorescence could indicate that this is a depauperate plant. Other features, such as the longer scales, achenes, and anthers, and the apiculate achenes represent differences perhaps worth of taxonomic recognition. However, two collections is a very limited sample, especially of a plant of extreme environments and further collections are necessary.

Specimens mapped (Fig. 4): CoAHuILA, western Coahuila, high limestone ridge with forest of Pinus pinceana, SW end of the Sierra de la Fragua, 1-2 km N of Puerto Colorado; abundant, coarse tufts 1-3 ft tall, on rocky slopes with scrub oaks and Pinus pinceana, 2 Sep 1941, I. M. Johnston 8763 (Type: GH, LL, TEX); Nuevo LeÓN, Cañón Los Aires, Cañón de Santa Catarina, en las paredes abruptas, 700-800 m, May 1943, Hno. E. Lyonnet 3933 (MEXU).

Cypringlea evadens (C. D. Adams) Reznicek \& S. González, comb. et stat. nov. Basionym: Scirpus analecta var. evadens C. D. Adams, Ann. Missouri Bot. Gard. 78: 254. 1991. Type: Mexico. Chiapas, Mpio. Venustiano Carranza, steep slope with Quercus and Pinus, 3 mi. S of Aguacatenango along road to Pinola Las Rosas, 5600 ft., 25 June 1965, D. E. Breedlove 10570 (holotype, F; isotypes, DS, MICH). 
Plants in small, loose clumps with 1-4 culms; culms $25-75 \mathrm{~cm}$ tall, $0.6-1.9 \mathrm{~mm}$ wide, erect to spreading, triquetrous, coarsely ribbed, the angles antrorsely scabrous distally, smooth proximally. Leaves $6-8$, essentially basal; sheaths $5.5-9 \mathrm{~cm}$ long, greenish-white to stramineous, strongly ribbed, old sheath bases brownish, sometimes becoming slightly fibrous, the inner band whitish-hyaline to brown, membranous, finely veined, the apex shallowly concave to truncate or even prolonged into a short contra-ligule; ligule irregularly truncate to rounded, up to $1.8 \mathrm{~mm}$ long, the free portion brownish, $0.2 \mathrm{~mm}$ wide; blades linear, 8-65 $\mathrm{cm}$ long, 2-5(-5.8) mm wide, the widest 2.8-5(-5.8) $\mathrm{mm}$, more or less flat to somewhat V-folded, margins and keel of midvein antrorsely scabrous, especially distally, the apex becoming triquetrous. Inflorescence terminal, umbellate, (2.6-)4-14.5 cm long, 1.5-6 cm wide, with 3-6 primary involucral bracts, the lowermost 1-2 leaf-like and more or less equaling to slightly exceeding the inflorescence, the uppermost setaceous, lowest involucral bract $3-20 \mathrm{~cm}$ long, $0.7-1.5$ times as long as the inflorescence; primary rays $4-10$ ascending to curving, flexuous, compressed-trigonous to more or less terete, smooth or slightly antrorsely scabrous distally, the longest $3-9 \mathrm{~cm}$, second, and rarely third order branching present, with the spikelets ultimately solitary and long peduncled or in fascicles of 2-4 with typically two more or less sessile and the remainder peduncled; peduncles up to $24 \mathrm{~mm}$ long. Spikelets 6-60 per inflorescence, $20-80 \%$ peduncled, narrowly ellipsoid to lanceoloid, 5-10.5 mm long, 2-3 mm wide, cuneate at base, acuminate at apex; scales somewhat spreading, loosely spirally arranged, with 2-4 sterile scales at the base of the spikelet (excluding the prophyll) and 8-24 fertile scales; fertile scales 1.7-2.8 mm long, 1-1.4 mm wide, ovate, acute to obtuse, often with the midvein prolonged as a short mucro, reddish brown with a green to brown, 3-nerved mid-zone. Achene 1.3-1.9 mm long, 0.8-1.1 mm wide, dark brown, obovate to elliptic-obovate, flattened-trigonous to more or less plano-convex or even slightly concavo-convex, more or less cuneate to a sessile base, rounded to the apex, finely papillose; style branches reddish, feathery with elongate papillae. Anthers 0.6-1.5 $\mathrm{mm}$ long, apiculate.

Known from Guerrero, Puebla, Oaxaca, and Chiapas, from ravines and slopes with mesophytic forest, pine-oak forest or open woods. It is separated from C. analecta by the transvolcanic belt, with no collections from northern Hidalgo to the Puebla-Oaxaca border. Alt. 1750-1850 m.

Specimens mapped (Fig. 4): ChiApas, Mpio. Venustiano Carranza, 3 mi. S of Aguacatenango along road to Pinola Las Rosas, $5600 \mathrm{ft}$., 22 July 1965, D. E. Breedlove 11204 (DS, MICH); Mpio. Jitotol, 6 mi. N of Jitotol, ca $92^{\circ} 40^{\prime} \mathrm{W}, 17^{\circ} 30^{\prime} \mathrm{N}$. 5100 ft., Sep 1971, R. F. Thorne \& E. W. Lathrop 41357 (DS); Guerrero, rd from 
Milpillas to Atoyac de Alvarez, 9 mi WSW of Xochipala, $5400 \mathrm{ft}$., 30 June 1982, $W$. W. Thomas 2830 with J. Rawlins \& O. Sholes (MICH); OAXACA, $97 \mathrm{~km}$ by road S of Teotitlan on road to Oaxaca, 1850 m, 10 Oct 1983, W. R. Anderson 12997 (MICH); Puebla, Cerro de Paxtle, in the vicinity of San Luis Tultitlanapa, July 1907, C. A. Purpus 2889 (GH, MO, US).

\section{ACKNOWLEDGEMENTS}

Thanks are given to Mark Strong by comments, to Susan Reznicek for help with the images, to Jorge Tena for the map, and to Tom Wendt for sending images and data on the type of C. coahuilensis. The curators of ANSM, CIIDIR, ENCB, IEB, GH, LL, MEXU, MICH, and TEX provided facilities to revise material. Socorro González acknowledges support for research of the COFAA and EDI, Instituto Politécnico Nacional.

\section{LITERATURE CITED}

Adams, C. D. 1991. New combinations and a new variety in the Cyperaceae of Mesoamerica. Ann. Missouri Bot. Gard. 78(1): 254.

Adams, C. D. 1994. Cyperaceae, Isolepis, Oxycaryum, Scirpus, Bolboschoenus, Schoenoplectus. Flora Mesoamericana 6: 447-449.

Beetle, A. A. 1947. Scirpus. North Amer. Fl. 18: 481-504.

Bruhl, J. 1995. Sedge genera of the world: relationships and a new classification of the Cyperaceae. Austral. Syst. Bot. 8: 125-305.

Espejo Serna, A. \& A. L. López-Ferrari. 1997. Las monocotiledóneas mexicanas, una sinopsis florística, parte V. Cyperaceae. Consejo Nacional de la Flora de México, Universidad Autónoma Metropolitana Iztapalapa y Comisión Nacional para el Conocimiento y Uso de la Biodiversidad. México, D.F. 98 pp.

Goetghebeur, P. 1998. Cyperaceae. In: Kubitzki, K. (eds.). The families and genera of vascular plants. Vol. 4. Springer-Verlag. Berlin. pp. 141-190.

Reznicek, A. A. 2005. Northern Mexican Cyperaceae, some biogeographical and conservation problems. Resúmenes. Simposio internacional El Conocimiento Botánico en la Gestión Ambiental y el Manejo de Ecosistemas. CIIDIR-IPN Durango y Sociedad Botánica de México. Durango, Dgo. pp. 25-26.

Strong, M. T. 2003. Cypringlea, a new genus of Cyperaceae from Mexico. Novon 13: 123132. 